\title{
Biodiversity and ecosystem functioning in soil: The dark side of nature and the bright side of life
}

\author{
This article belongs to Ambio's 50th Anniversary Collection. Theme: Agricultural land use
}

\author{
Lijbert Brussaard
}

Published online: 13 March 2021

Darwin not only revealed the origin of species in the evolutionary playground of Planet Earth, but also made us aware that the soil fauna actually acts as an engine of ecosystem functioning (Darwin 1881). This message was largely lost on the mainstream ecologists for more than 100 years (out of sight-out of mind?). There was some resurgence in the soil textbooks of the early 1900s. For example, in his landmark book Factors of soil formation, Jenny (1941) recognized 'organisms' as one of the soil forming factors, next to parent material, climate, topography and time. However, since the 1950s, the importance of the soil biota for ecosystem functioning became obscured in the literature on the suitability of soils for agriculture and other land use purposes. Why? Most likely because the importance of the soil biota for crop root growth, nutrient supply and suppression of harmful organisms was increasingly supplanted by intensive use of external inputs such as machinery, artificial fertilizers and pesticides. In other words, human ingenuity and technology became the focus and driver of productivity, dominant over the role played by nature.

As early as the 1960s, the environmental impacts of input-intensive agriculture began to emerge in the research literature. Conservationists began to wonder if the loss of species and the collapse of natural ecosystems could be stemmed by evidence for the possible quantitative importance of biodiversity for ecosystem functioning and services. With strong links established between intensive agricultural practices, environmental problems and soil processes, soil biologists saw the necessity of reminding the soil science and agronomy communities of the lessons taught by Darwin and his early successors (Lavelle 2000). However, in both research and policy arenas the tone was set mainly by plant and, to a lesser extent, animal ecologists, most of whom were still oblivious of life in the soil (Schulze and Mooney 1994; Mooney et al. 1996).

But the tide began to change. A Scopus search for (biodiversity AND function* AND soil) in title, abstract \& keywords shows a rise from only a few hits around 1994 to about 150 in 2004 and more than 500 in 2018 . Hence, the 1997 Ambio article Biodiversity and ecosystem functioning in soil (Brussaard et al. 1997) was, indeed, timely, in setting the scene for future publications. The article was one of the first of a total of 43 scientific publications of the SCOPE $^{1}$ project on Soil and Sediment Biodiversity and Ecosystem Functioning (SSBEF; 1996-2004), inspired and led by the visionary Professor Diana Wall of Colorado State University, USA. SCOPE's mandate at the time was "to assemble, review and assess available data on humanmade environmental change and the effects of these changes on people". Around the start of the project, SCOPE syntheses were mainly about the major element cycles. The SSBEF project was to be a game changer in focusing on the organisms involved.

The Ambio article was conceptualized during the first SSBEF workshop in The Netherlands in the spring of 1997 on soil and sediment biodiversity and ecosystem functioning. It was soon to be followed by workshops in autumn 1997, again in The Netherlands, on above-/belowground biodiversity relationships, and in autumn 1998 in the USA, on the role of soil and sediment biodiversity in the functioning of critical transition zones. A common thread in all activities was the explicit consideration of linkages between soils and sediments and between the interfaces between sediment and water or terrestrial belowand aboveground. The outcomes of those workshops and ensuing research were discussed at the concluding meeting

\footnotetext{
${ }^{1} \mathrm{https} / / /$ scope-environment.org/.
} 
in the USA in autumn 2002 on the assessment of the most critical taxa, functions and habitats of soil and sediment biodiversity in terms of vulnerability, sustainability and management options, leading in 2004 to the final publication Sustaining Biodiversity and Ecosystem Services in Soils and Sediments (Wall 2004). This was, in its own words "the first rigorous synthesis of the ability of the biodiversity both within and across soils and sediments to provide ecosystem services". In that spirit, a Policy Brief (UNESCO 2007), and a popular book (Baskin 2005) were also published soon after.

However, to put the spirit of that period in perspective, another noteworthy and, in fact, earlier initiative, also aimed at elucidating the importance of soil biodiversity for ecosystem functioning and services should be mentioned: the Tropical Soil Biology and Fertility (TSBF) program. It was inspired and led by the equally visionary Professor Mike Swift, lead author of the influential book Decomposition in Terrestrial Ecosystems (Swift et al. 1979). The TSBF program, up and running independently from 1984 onward, was incorporated as a separate branch in the International Centre for Tropical Agriculture $\left(\mathrm{CIAT}^{2}\right)$ in 2001 because of its importance for tropical agriculture. Not surprisingly, several of the same scientists participated in both TSBF and SSBEF. Both programs resulted in landmark books and reviews in which soil ecology took center stage, with due attention to the diversity and functional composition of soil communities and associated ecosystem processes and services (Ritz et al. 1994; Cadish and Giller 1996; Lavelle and Spain 2001; Wardle 2002; van Noordwijk et al. 2004; Wardle et al. 2004; Bardgett 2005), methods of investigation (Anderson and Ingram 1993) and linking newly acquired knowledge to practice (Woomer and Swift 1994; Lavelle et al. 1999; Wolters et al. 2000; Jarvis et al. 2007; Wall 2012). All of the publications confirmed the conclusion that the role of the biota in providing ecosystem services in soils and sediments declines as human use intensifies (Wall et al. 2004).

When Diana Wall, who is still going strong at CSU, was asked in a recent BioScience podcast ${ }^{3}$ what she would like to be remembered for, she said: "I hope that we, a number of us, my colleagues who work on these unseen, hidden foodwebs beneath our feet, are remembered for getting them into mainstream ecology and into the decisions we make on how we manage land. This is changing, but for a number of years they were really not considered unless they were pests or pathogens, but now there is many more ways we look at the diversity of life beneath our feet." Indeed, several of the scientists involved have made serious efforts to achieve just that by publishing many more

\footnotetext{
2 https://ciat.cgiar.org/.

${ }^{3}$ http://bioscience-talks.aibs.org/in-their-own-words-diana-wall.
}

primary research articles, books and reviews after the termination of the SSBEF project and by accepting responsible roles in professional organizations. In several cases, efforts were part of international programs such as the Global Soil Biodiversity Initiative and the International Year of Soils (2015). In addition, the community of researchers also contribute(d) to programs with a broader mandate than just soils, e.g. the Millennium Ecosystem Assessment $^{4}$ and the Sustainable Development Goals ${ }^{5}$; DIVERSITAS: International Programme of Biodiversity Science $^{6}$ which merged into Future Earth ${ }^{7}$; and IPBES: Intergovernmental Science-Policy Platform on Biodiversity and Ecosystem Services ${ }^{8}$, in an effort to make "the dark side of nature" part of "the bright side of life".

\section{REFERENCES}

Anderson, J.M., and J.S.I. Ingram. 1993. Tropical Soil Biology and Fertility: A Handbook of Methods. Wallingford: CABI. http:// www.asb.cgiar.org/publication/handbook-tropical-soil-biologysampling-and-characterization-below-ground-biodiversity.

Bardgett, R.D. 2005. The Biology of Soil-A Community and Ecosystem Approach. Oxford. https://www.oxfordscholarship. com/view/10.1093/acprof:oso/9780198525035.001.0001/acprof9780198525035.

Baskin, Y. 2005. Under Ground: How Creatures of Mud and Dirt Shape Our World. Washington, D.C: Island Press. https:// islandpress.org/books/under-ground.

Brussaard, L., V.M. Behan-Pelletier, D.E. Bignell, V.K. Brown, W. Didden, P. Folgarait, C. Fragoso, D.W. Freckman, et al. 1997. Biodiversity and Ecosystem Functioning in Soil. Ambio 26: 563-570.

Cadish, G., and K.E. Giller. 1996. Driven by Nature-Plant Litter Quality and Decomposition. Wallingford: CABI. https://www. cabi.org/bookshop/book/9780851991450/.

Darwin, C. 1881. The Formation of Vegetable Mould through the Action of Worms - with Observations on their Habits. London: John Murray.

Jarvis, D.I., C. Padoch, and H.D. Cooper (eds.). 2007. Managing Biodiversity in Agricultural Ecosystems. New York: Columbia University Press. http://cup.columbia.edu/book/managingbiodiversity-in-agricultural-ecosystems/9780231136488.

Jenny, H. 1941. Factors of Soil Formation-A System of Quantitative Pedology. New York: Dover.

Lavelle, P. 2000. Ecological Challenges for Soil Science. Soil Science 165: 73-86.

Lavelle, P., and A. Spain. 2001. Soil Ecology. Springer. https://www. springer.com/gp/book/9789401752817.

Lavelle, P., L. Brussaard, and P. Hendrix (eds.). 1999. Earthworm Management in Tropical Agroecosystems. Wallingford: CABI.

\footnotetext{
${ }^{4}$ www.millenniumassessment.org.

5 https://sustainabledevelopment.un.org/.

${ }^{6} \mathrm{http}: / / \mathrm{www}$.diversitas-international.org/.

${ }^{7}$ https://futureearth.org/.

${ }^{8}$ https://ipbes.net/.
} 
Mooney, H.A., J.H. Cushman, E. Medina, O.E. Sala, and E.-D. Schulze (eds.). 1996. Functional Roles of Biodiversity-A Global Perspective. SCOPE report 55. Chichester: Wiley.

Ritz, K., J. Dighton, and K.E. Giller (eds.). 1994. Beyond the Biomass-Compositional and Functional Analysis of Soil Microbial Communities. Chichester: Wiley. https:// onlinelibrary.wiley.com/doi/abs/10.1002/jobm.3620350307.

Schulze, E.-D., and H.A. Mooney (eds.). 1994. Biodiversity and Ecosystem Function. https://www.springer.com/gp/book/ 9783540581031.

Swift, M.J., O.W. Heal, and J.M. Anderson. 1979. Decomposition in Terrestrial Ecosystems. Oxford: Blackwell.

UNESCO. 2007. Hidden assets: Biodiversity Below-Surface. SCOPE Policy Brief http://www.scopenvironment.org/unesco/USPB05 SOIL_En.pdf.

Van Noordwijk, M., G. Cadish, and C.K. Ong (eds.). 2004. Belowground Interactions in Tropical Agroecosystems-Concepts and Models with Multiple Plant Components. Wallingford: CABI. https://www.cabi.org/bookshop/book/9780851996738/.

Wall, D.H. (ed.). 2004. Sustaining Biodiversity and Ecosystem Services in Soils and Sediments. SCOPE report 64. Washington D.C.: Island Press https://islandpress.org/books/sustainingbiodiversity-and-ecosystem-services-soils-and-sediments.

Wall, D.H. (ed.). 2012. Soil Ecology and Ecosystem Services. Oxford: Oxford University Press. https://www.oxfordscholarship. com/view/10.1093/acprof:oso/9780199575923.001.0001/acprof9780199575923.

Wall, D.H., R.D. Bradgett, A.P. Covich, and P.V.R. Snelgrove. 2004. Understanding the Functions of Biodiversity in Soils and Sediments will Enhance Global Ecosystem Sustainability and Societal Well-
Being. In Sustaining Biodiversity and Ecosystem Services in Soils and Sediments, ed. D.H. Wall, 249-254. Washington D.C.: Island Press. https://islandpress.org/books/sustaining-biodiversity-and-ecosystemservices-soils-and-sediments.

Wardle, D.A. 2002. Communities and Ecosystems—Linking the Aboveground and Belowground Components. Princeton. https://press. princeton.edu/books/paperback/9780691074870/communities-andecosystems.

Wardle, D.A., R.D. Bardgett, J.N. Klironomos, H. Setälä, W.H. van der Putten, and D.H. Wall. 2004. Ecological Linkages Between Aboveground and Belowground Biota. Science 304: 1629-1633.

Wolters, V., W.L. Silver, D.E. Bignell, D.C. Coleman, P. Lavelle, W.H. van der Putten, P. de Ruiter, J. Rusek, et al. 2000. Effects of Global Changes on Above- and Belowground Biodiversity in Terrestrial Ecosystems: Implications for Ecosystem Functioning. BioScience 50: 1089-1098.

Woomer, P.L., and M.J. Swift (eds.). 1994. The Biological Management of Tropical Soil Fertility. Chichester: Wiley. https://www. wiley.com/en-nl/The+Biological+Management+of+Tropical+ Soil+Fertility-p-9780471950950.

Publisher's Note Springer Nature remains neutral with regard to jurisdictional claims in published maps and institutional affiliations.

\section{Lijbert Brussaard $(\square)$}

Address: Soil Biology Group, Wageningen University \& Research, P.O. Box 47, 6700 AA Wageningen, The Netherlands.

e-mail: lijbert.brussaard@wur.nl 